日臨外会誌 $64(6) ， 1468-1472 ， 2003$

症例

脾破裂を繰り返した脾原発悪性リンパ腫の 1 例

\author{
戸田中央総合病院外科 \\ 黒田直樹 日馬幹弘 大久保和 隆 \\ 岡田佳平野牛道晃山梨美紀夫
}

症例は76歳の男性で, 外傷の既往なくショックを伴った腹部全体の疼痛にて緊急入院 した.この患者は 9 カ月前にも原因不明の脾破裂による腹腔内出血のため入院し，この ときは保存的に軽快していた. 今回入院時には汎血球減少と造影腹部 CT にて腹空全体 に出血を認め，前回と同じ部位に脾荿の破裂像を認めた。翌日，賽血が進行し全身状態 が增悪したため乑急手術となった。開腹時，脾被膜は散在性に破れ怒張した血管が露出 していた。このうち 2 箇所から拍動性出血が認められた。側副血行の発達仙認めず，外 見上,肝, リンパ節にも異常は認めなかった。摘出脾葴は大きさ $32.5 \times 19.0 \mathrm{~cm}$, 重さ 3,050 g で病理検査で病理検査で non-Hodikin B 型リンパ腫, Diffuse large cell type と診断 された. 術後 6クールの CHOP 変法 (CPA, THP, VCR, Pred) を施行し, 現在まで 完全緩解を維持している．悪性りンパ腫に脾破裂を伴う重要な要因の一つとして白血病 化による急速な腫瘍細胞の増殖が考えられた。

索引用語：spontaneous splenic rupture, malignant lymphoma

はじめに

特発性脾破裂は稀な病態であるが，重篤な合併症で ある腹腔内出血を生じるため迅速な外科的処置を必要 とする。しかし，発症時にはその原因が確定されてお らず,多くの症例は急性腹症として摘脾が行われた後, 組織学的所見により診断がなされている.今回, われ われは原因不明の再燃する脾破裂に対して，摘出によ り診断を得た脾原発悪性リンパ腫の 1 例を経験したの て，文献的考察を加え報告する。

$$
\text { 症例 }
$$

患者：76歳, 男性.

初回時主訴: 上腹部痛, 吐血.

既往歴：2000年 4 月, 他院にて脾腫を指摘され, 特 発性門脈圧穴進症の診断で手術を勧められたが拒否し ている。

家族歴：特記すべことなし。

初回時病歴：2001年 6 月 13 日より左側腹部痛が出現 したが, 鎮痛阂で改善していた。15日，コーヒー残查

2002年11月29日受付 2003 年 2 月19日採用

〈所属施設住所〉

₹335-0023 戸田市本町 $1-19-3$
様の嘔吐があり，近医を受診し著明な實血を指摘され， 精查目的にて当院消化器内科を紹介され来院した。

初回時経過：左季肋部に最も強い圧痛を訴えてい た. 筋性防御は軽度であり, 触診にて巨大な脾臓を触 知した。採血にて WBC $3,400 / \mathrm{mm}^{3}$, RBC $147 \times 104 /$ $\mathrm{mm}^{3}$, Hb $4.3 \mathrm{~g} / \mathrm{dl}$, Ht $14 \%$, Plate $47,000 / \mathrm{mm}^{3}$ と沉 血球減少が認められた. CRP 16.9mg/dl, LDH 1,606 IU/1 と著明な上昇を認め, 肝·腎機能の一部 (GOT 49 $\mathrm{IU} / 1$, BUN $56 \mathrm{mg} / \mathrm{dl}$, Creatinin $2.1 \mathrm{mg} / \mathrm{dl})$ に軽度の 異常がみられた，同日，淔厚赤血球を輸血し，緊急内 視鏡を施行した。食道静脈瘤を認め(図 1 )，6 籄所の 内視鏡的結絷を施行し，吐血は沈静化した。腹部 CT

（図 2 ）にて被膜下血腫を伴った脾腫を，超音波にて わずかな血性腹水が認められたが，肝硬変の所見はみ られなかった．腹部血管造影では明らかな側副血行路 は認められず，脾臓の実質一部に楔状の無血管域がみ られ，出血部位と考えられた（図 3)，保存療法により 全身症状改善し, 循環動態も安定しており, informed consent (IC) にて手術を拒否したため 7 月 6 日退院と し，外来にて経過観察となった. 再燃時主訴：腹痛（腹部全体痛）.

再燃時病歴および経過：2002年 3 月15日末明より突 


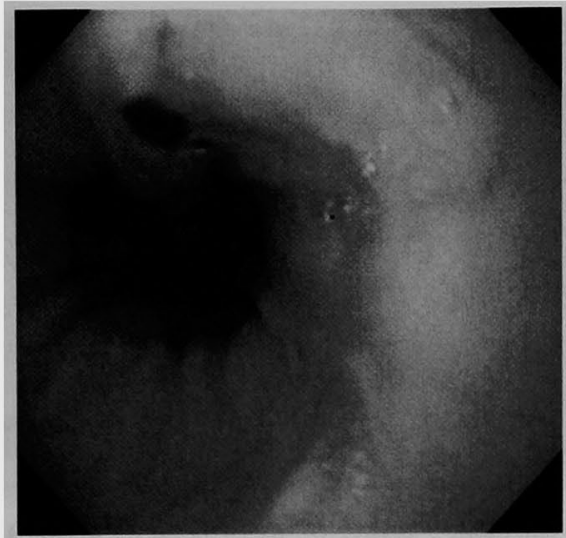

図 1 緊急内視鏡所見：12時方向に謴㾇を 伴った静脈瘤（F1）を認めたほか，9時, 4 時方向にも静脈瘤がみられた。

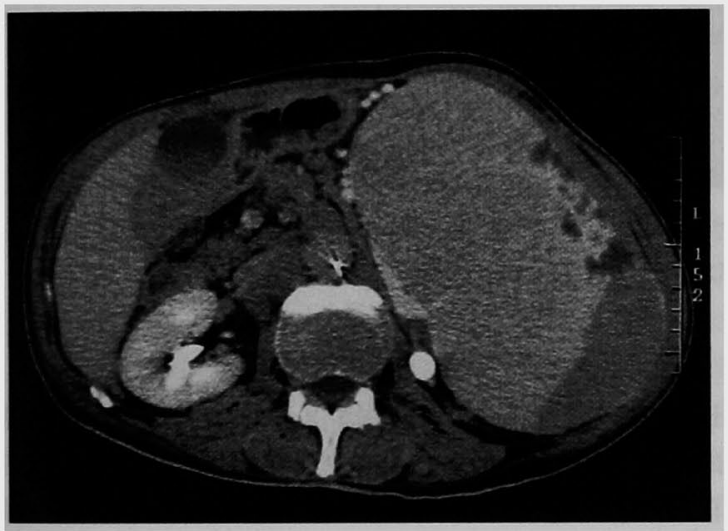

图 2 初回時腹部 CT 所見：脾臟被膜下の血腫と破裂部 が認められる。

然の腹部全体の痛みを生じたため, 救急車にて来院し た。意識は清明であったが，血圧は触診にて84/ $\mathrm{mmHg}$, 脈拍 $64 / \mathrm{min}$ 整, 体温 $35.7^{\circ} \mathrm{C} て ゙$ pre-shock 状態 であった．腹部は緊満状態て筋性防御がみられた。緊 急採血にて WBC $3,800 / \mathrm{mm}^{3}, \mathrm{RBC} 159 \times 104 / \mathrm{mm}^{3}$, $\mathrm{Hb} 5.8 \mathrm{~g} / \mathrm{dl}, \mathrm{Ht} 19.2 \%$, Plate $16,000 / \mathrm{mm}^{3}$ と汎血球減 少がみられた。腹部単純 X線では腹部全体の淡い陰影 と胃泡の偏位か，緊急腹部 CT にて著明な脾腫と内部 の破裂所見および腹腔全体への出血がみられたため

(図 4)，脾腫の再破裂と診断した。濃厚赤血球・血小 板輸血を施行し，小康状態となった．保存的治療を希 望するも，翌日，貧血が進行し，全身状態も悪化した ため, 保存療法の限界と判断され, 当科へ転科となっ

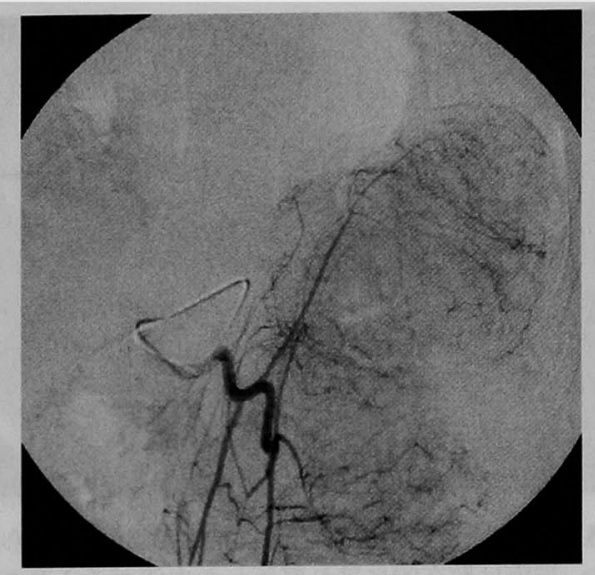

図 3 腹部血管造影所見：脾臓実質の一部 に楔状の無血管野を認めた。

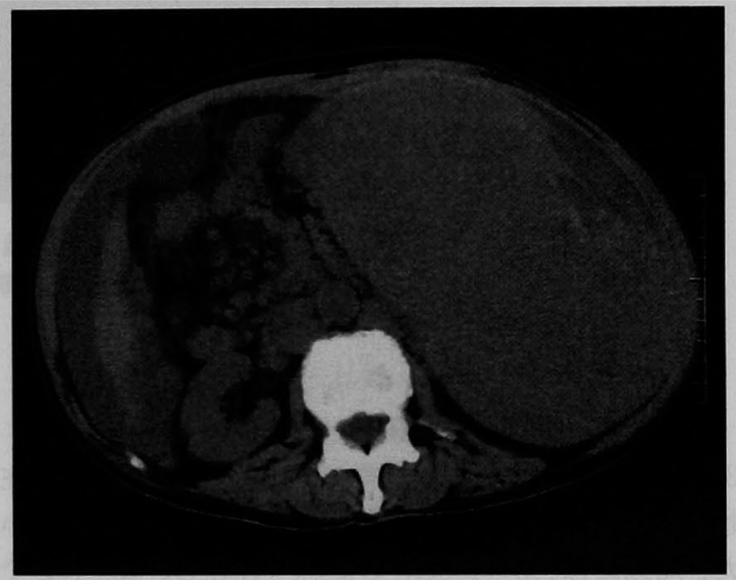

図 4 再発時造影腹部 CT 所見：腹腔全体に出血が及ん でおり，前回と同じ部分に脾蔵の破裂像が認められた。

た．手術の承認が得られたため特発性門脈圧穴進症に よる脾蔵破裂の診断で緊急手術となった。

手術所見（図 5 ）：開腹すると腹腔内全体に凝血塊を 含む大量の出血を認めた. 脾㵴下方 $1 / 3$ の部位でとこ ろどころで被膜が裂けており，血管が露出していた。 2 筒所の怒張した血管からの拍動性出血を認めた。側 副血行の発達はみられず，肝，リンパ節にも異常所見 はみられなかった．巨大脾腫のため直視下の血管処理 ができず，触診にて脾動静脈を結染し摘出した．出血 量は8,648gによよび, セルセイバーを使用しながら遂 行した.術後は扱管のまま集中治療室にて管理を行い， 術後 4 日目に全身状態が改善したため，一般病棟に㷌 室した。 


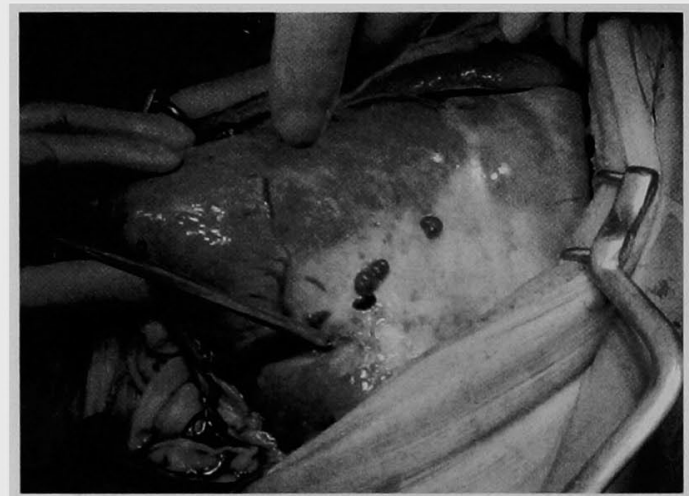

図 5 手術所見：脾破裂部から拍動性出血がみられ た。被膜は散在的に破れ怒張した血管がみられた。

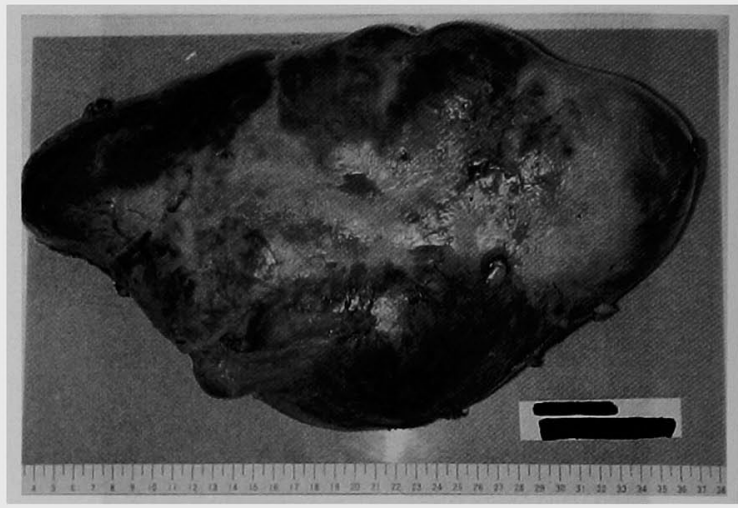

図 6 摘出標本：脾蔵は $32.5 \times 19.0 \mathrm{~cm}$ で, 重量は3,050g であった。

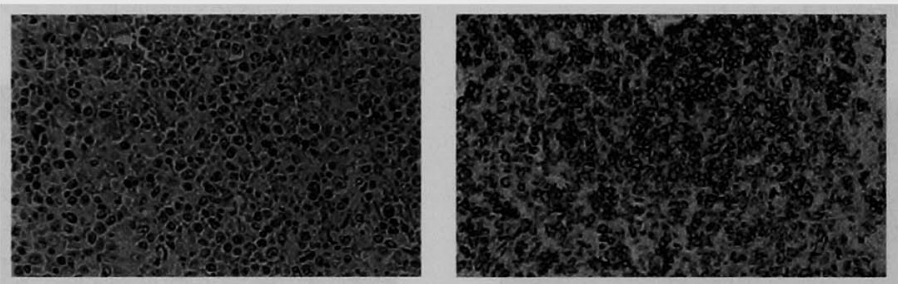

図 7 病理組織学的所見：組織学的に non-Hodikin B 型リンパ腫 diffuse large cell type と診断された (左: H. E.染色 $\times 100$, 右 : L -26 染色 $\times 50$ ).

摘出標本（図 6)：脾荿は全体が暗赤色で $19.0 \times$

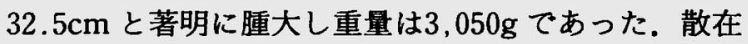
性の被膜の破裂がみられ, 怒張した血管が露出してい た. 周井には $1.0 \times 1.3 \mathrm{~cm}$ の副脾も存在し, 重さ $10 \mathrm{~g} て$ あった。

病理組織学的所見（図7）：ほとんど全域で異型細 胞が増殖しており, 被膜にも浸潤を認めた。梗塞巣は みられなかった。異型細胞は核が腫大し, 核小体が著 明であり分裂像も多数認められた。免废組織染色にて L-26(t), CD79a (+), UCHL-1 (-), CD3 (-), CD57 (-), Ki-1(十の所見が得られ LSG 分類の non-Hodgkin B 型リンパ腫 diffuse large cell type と診断された.

術後14日目の採血にて, 血液像中に大型で, 核/細胞 質比の大きく，核小体を有する細胞が54\%に認められ， 白血病化と考えられた. 術後状態も安定したため, 血 液内科へ転科となった。この後, 内科による検查にて 可溶性 IL-2 受容体も陽性 $(1,272 \mathrm{U} / \mathrm{ml})$ で, 骨鲔穿刺 にて85chromosomes (7q+)，45，X, - Y,46XY の染 色体異常の細胞が認められた。術後25日目から CHOP 変法 (CPM 1,000mg, THP 40mg, VCR $1 \mathrm{mg}, \mathrm{PRED}$ 100mg day1-5/body）療法が 2 クール施行され，一時 的に腹腔内リンパ節に腫大みられるも改善し， 5 月29 日退院. 外来にてさらに 4 クール施行, 現在も完全緩 解の状態で, 内科にて経過観察中である.

\section{考 察}

外傷によらない特発性脾破裂 (spontaneous splenic rupture）は稀な病態であり，基礎疾患が潜在している ことが多い. 以前は感染症の報告が多かったが1), 近 年, 人口の高齢化に伴い悪性腫場およびその転移など による報告が多くみられるようになってきている゙2. 腫瘍細胞の浸潤により病的状態にある脾葴の非外傷性 破裂は pathologic rupture と呼ばれている(5). 造血器 疾患による原因が多いが，悪性リンパ腫を基礎疾患と して脾破裂が併発した報告は1946年の Littlefield ${ }^{3)}$ 報告以来, 当科での検索範囲においては自験例を含め て34例であった ${ }^{15)}$. 本邦では岩渕ら“代1987年に報告 した 2 例が最初で，自験例は12例目である。このうち, 術前に悪性リンパ腫の診断のついていたものはわずか に 1 例のみであっだ．自験例では多くの症例にみら れる表在リンパ節の腫大もなく，数年前から特発性門 
脈圧六進症と診断されていたため，本症を推測するこ とは極めて困難であった。この門脈圧六進が続発性に 発生したものか, 単に合併したものかの判断は困難で あるが，臨床経過より脾臟への浸潤による二次的なも のと推測している.

脾破裂の機序として岩消らはHynes の説 (睡崵細胞 の脾被膜への直接浸潤, 脾梗塞とそれに続発する被膜 下出血および被膜の破綻. 血液凝固能異常(5), Sonobe らの説（腫瑒細胞の著しい増殖による脾実質内圧の急 激な上开()), Thomson の説(脾腫により過進展されて いる被膜に対する横隔膜や腸管運動による機械的刺 激》)を紹介している。これらのうち，脾梗塞は主要因 とは考えられていない。これは, 白血病症例において は約50\%に脾梗塞がみられるが, 非破裂例でもしばし ばみられること齐, 脾梗塞は慢性白血病に多いにもか かわらず破裂するのは急性白血病に多いこどなどに よる.悪性リンパ腫については頻度が少ないため明確 にされていないが, 梗塞巣の部位と破裂部位が一致し ないことが示されている゙. 事実, 自験例でも脾梗塞は 認められなかった。 また, 悪性リンパ腫で破裂した脾 臓の重量は過去の報告例では200から3,000g までと差 があり ${ }^{31}$, 脾臓の重量および脾腫も破裂の主要因とは 考えにくい(2)とされている。岩渕ら゙は白血病化した 悪性リンパ腫によって急速に腫場細胞が増殖した結 果, 脾破裂が起きたと報告している，自験例を含め記 載のあった15例中12例 $(80.0 \%)$ に骨髄浸潤が認めら れており，急速な腫湯細胞の増殖は重要な要因と考元 られる ${ }^{10}$. 自験例は白血病化が確認されており,脾破裂 の機序としては, 脾実質内での腫瘍細胞の増生による 脾葴の腫大と被膜の破綻が主因となり，そこに出血傾 向の存在と, 嘔吐による門脈圧上昇が重なり合い, 露 出した血管に直接外力が作用した結果と推測してい る.

治療としては, 循環動態が不安定で全身状態が悪化 したため迷わずに開腹，摘脾術を選択した。極めて著 明な脾腫であり, 胃脾間膜, 脾門部の処理共に直視下 では行えず, 8,648g と大量出血となった。セルセイバ 一を使用しながら何とか手術を終了しえた。脾機能を なるへくく温存するような治療法が可能な場合もある が(11 13)，まずは救命を第一に考えることが必要と思わ れる. 自験例でもみられたように，脾臓自体の脆弱性 も上昇しているため, 過度の触診などは避けることが 必要である，とも言われている4).

自験例では, Gupta $ら^{14)}$ の脾原発性悪性リンパ腫の
診断基準は完全には満たしていない，それは，肝生検 を施行していないことと化学療法中に一時的に CT て 腹腔内リンパ腫脹がみられたためである。しかし， Gupta らの条件をすべて満たす症例はむしろ少なく， non-Hodgkin リンパ腫が元来, 多中心性の進展様式を とることを考えれば原発の意義は薄れる ${ }^{11}$ 考えられ ており, 臨床経過からすると脾病変が原発で, その後, 骨髄へ浸潤し脾破裂をきたした可能性が大きいと考元 られ，脾原発の悪性リンパ腫と考えて妥当であろうと 思われた。

脾破裂による死亡率は極めて高く，多くは表在リン パ節などの他蔵器病変を認めている。一方, 脾㵴のみ に限局する場合は切除により予後は良好とされてい $3^{16)}$. 本症例は白血病化を生じていたが, 幸いにも, 化 学療法が奏効したため完全緩解を維持できているが, 今後も慎重なフォローアップが必要と考えている.

\section{文献}

1）松井 寛, 安藤重満, 标原堅式他：悪性リンパ腫 を基碟疾患とした脾破裂の1例。日消外会誌 $27: 2166-2170,1994$

2）野田八哃，福岡婜一，宮森弘年他：脾転移により 特発性脾破裂をみた肝細胞暍の 1 例. 肝淢 23 ： 1083-1087, 1982

3) Littlefield JB: Spontaneous rupture of the spleen. Syrg Obstet Gynecol 82 : 207-211, 1946

4）岩㴊敬一，高木敏之：脾破裂をきたした悪性リン パ腫の 2 例. 臨血 $28: 752-755,1987$

5) Hynes HE: Spontaneous rupture of theespllen in acute leukemia. Report of 2 cases. Cancer $17: 1356-1360,1964$

6) Sonobe $H$, Uchida $H$, Doi $K$, et al : Spontaneous rupture of the spleen in acute myeloid leukemia. Acta Pathol Jpn 31 : 309-315, 1981

7) Thomson WHF : Diffuse lymphocytic lymphoma with splenic rupture. Postgrad Med J 45: 50-51, 1969

8) Knoblich $R$ : Pathologic (so-called spontaneous) rupture of the spleen in leukemia and lymphoma. Mich Med 65:105-110, 1966

9) Bauer TW, Haskins GE, Armitage JO : Splenic rupture in patient with hematologic malig. nancies. Cancer $48: 2729-2733,1981$

10）土橋史明, 倉石安庯, 小林直他: 脾破裂を伴っ た悪性りンパ盾の 1 例. 臨血 $34: 190-193,1993$ 
11）堀池重治, 前川和彦, 浅井 靖他：脾損傷の保存 的治療に扔けるTranscatheter Arterial Embolizationの役割. 日外傷研会誌 $3: 276-281$, 1989

12）真々田祐厷, 隅崎達夫, 田島展之地：肝脾外傷に 対する経力テーテル的動脈塞栓術の応用，腹部救 急祄療の進步 $11: 339-342,1991$

13）前川和彦：脾縫合. 救急医 $8: 474-475,1984$

14) Gupta TD, Coomes B, Brasfield RD : Primary malignant neoplasm of the spleen. Surg Gynecol Obstet 120:947-960, 1965

15) Strickland AH, Marsden KA, Mcardle J, et al : Pathologic Splenic Rupture as the Presentation of Mantle Cell Lymphoma. Leukemia and Lymphoma $41: 197-201,2001$

16）米谷文雄, 郭 宗宏, 使原 央他：脾破裂を伴っ た脾原発悪性りンパ腫の 1 例一本邦報告例の集計 一日消外会誌 $28: 461,1995$

\title{
RECURRENT SPONTANEOUS SPLENIC RUPTURE IN PRIMARY SPLENIC MALIGNANT LYMPHOMA
}

\author{
Naoki KURODA, Mikihiro KUSAMA, Kazutaka OHKUBO, \\ Kahei OKADA, Michiaki YAGYU and Mikio YAMANASHI \\ Department of Surgery, Toda Central Hospital
}

A 76-year-old man with no history of trauma admitted in an emergency due to pain in the whole abdomen with hypovolenic shock was diagnosed with hemoperitoneum by spontaneous splenic rupture and discharged without operation 9 months earlier. Laboratory findings at admission showed marked pancytopenia. Enhanced abdominal computed tomography (CT) scan showed massive hemoperitoneum and splenic rupture. One day later, an emergency laparotomy was conducted due to progressive anemia and the man's poor general condition. Operative findings included extensive coagulation, dark reddened giant splenomegaly, and active bleeding by splenic rupture from the serosa to parenchyma. Splenectomy was done but no lymph node swelling or liver findings were seen. The resected spleen was $32.5 \times 21.0$ $\mathrm{cm}$, weighted $3,050 \mathrm{~g}$, and was infiltrated by malignant diffused large-cell lymphoma. Postoperative chemotherapy with 6 cycles of modified CHOP (CPA, THP, VCR, Pred) has kept the patient in complete regression.

Leukemic change is an important factor in spontaneous rupture in malignant lymphoma. 